University of Wollongong

Research Online

Faculty of Engineering and Information

Faculty of Engineering and Information

Sciences - Papers: Part A

Sciences

$1-1-2013$

\title{
Effect of annealing on properties of carbonaceous materials. Part III: macro and microstrengths
}

Xing Xing

University of New South Wales, x.xing@unsw.edu.au

Guangqing Zhang

University of Wollongong, gzhang@uow.edu.au

Mark Dell'Amico

CSIRO Energy Technology, Australia

George Ciezki

Temco, George.Ciezki@BHPBilliton.com

Qingbo Meng

Tasmanian Electro Metallurgical Company, meng123qb@sina.com

See next page for additional authors

Follow this and additional works at: https://ro.uow.edu.au/eispapers

Part of the Engineering Commons, and the Science and Technology Studies Commons

Research Online is the open access institutional repository for the University of Wollongong. For further information contact the UOW Library: research-pubs@uow.edu.au 


\title{
Effect of annealing on properties of carbonaceous materials. Part III: macro and microstrengths
}

\begin{abstract}
Carbonaceous materials including cokes, chars, and pyrolyzed coals were annealed at temperatures ranging from $973 \mathrm{~K}$ to $1773 \mathrm{~K}(700 \mathrm{C}$ to $1500 \mathrm{C}$ ) in an inert atmosphere. Macro and microstrengths of original and annealed carbonaceous materials were characterized by the tensile strength and fracture toughness. Fracture toughness was determined for inert maceralderived component (IMDC) and reactive maceral-derived component (RMDC) using ultramicro indentation. Experimental data obtained by tensile tests were processed using the Weibull statistical method to find "inherent" strength. Tensile strength of chars and coals was significantly increased by annealing at temperatures ranging from $973 \mathrm{~K}$ to $1373 \mathrm{~K}$ (700 C to $1100 \mathrm{C})$; further increase in annealing temperature to $1773 \mathrm{~K}(1500 \mathrm{C})$ increased their tensile strength only slightly. Tensile strength of cokes decreased with the increasing annealing temperature; the major effect was observed in the temperature range from $1573 \mathrm{~K}$ to $1773 \mathrm{~K}$ ( $1300 \mathrm{C}$ to $1500 \mathrm{C}$ ). Fracture toughness of chars and coals was enhanced significantly by heat treatment at temperatures ranging from $973 \mathrm{~K}$ to $1373 \mathrm{~K}(700 \mathrm{C}$ to $1100 \mathrm{C}$ ) as a result of pyrolysis, while that of cokes increased slightly by heat treatment. Fracture toughness of IMDC was higher than RMDC.Macrostrength of carbonaceous materials was strongly affected by their porosity and microstrength. The effect of pore geometry on macrostrength was marginal. Decreasing the porosity was more effective compared with increasing the microstrength in improving the macrostrength of carbonaceous materials.

\section{Disciplines}

Engineering | Science and Technology Studies

\section{Publication Details}

Xing, X., Zhang, G., Dell'Amico, M., Ciezki, G., Meng, Q. \& Ostrovski, O. (2013). Effect of annealing on properties of carbonaceous materials. Part III: macro and microstrengths. Metallurgical and Materials Transactions B: Process Metallurgy and Materials Processing Science, 44 (4), 870-877.
\end{abstract}

\section{Authors}

Xing Xing, Guangqing Zhang, Mark Dell'Amico, George Ciezki, Qingbo Meng, and Oleg Ostrovski 


\title{
Effect of Annealing on Properties of Carbonaceous Materials. Part III: Macro and Microstrengths
}

\author{
XING XING, GUANGQING ZHANG, MARK DELL'AMICO, GEORGE CIEZKI, \\ QINGBO MENG, and OLEG OSTROVSKI
}

\begin{abstract}
Carbonaceous materials including cokes, chars, and pyrolyzed coals were annealed at temperatures ranging from $973 \mathrm{~K}$ to $1773 \mathrm{~K}\left(700{ }^{\circ} \mathrm{C}\right.$ to $\left.1500{ }^{\circ} \mathrm{C}\right)$ in an inert atmosphere. Macro and microstrengths of original and annealed carbonaceous materials were characterized by the tensile strength and fracture toughness. Fracture toughness was determined for inert maceralderived component (IMDC) and reactive maceral-derived component (RMDC) using ultramicro indentation. Experimental data obtained by tensile tests were processed using the Weibull statistical method to find "inherent" strength. Tensile strength of chars and coals was significantly increased by annealing at temperatures ranging from $973 \mathrm{~K}$ to $1373 \mathrm{~K}\left(700{ }^{\circ} \mathrm{C}\right.$ to $\left.1100{ }^{\circ} \mathrm{C}\right)$; further increase in annealing temperature to $1773 \mathrm{~K}\left(1500{ }^{\circ} \mathrm{C}\right)$ increased their tensile strength only slightly. Tensile strength of cokes decreased with the increasing annealing temperature; the major effect was observed in the temperature range from $1573 \mathrm{~K}$ to $1773 \mathrm{~K}\left(1300{ }^{\circ} \mathrm{C}\right.$ to $\left.1500{ }^{\circ} \mathrm{C}\right)$. Fracture toughness of chars and coals was enhanced significantly by heat treatment at temperatures ranging from $973 \mathrm{~K}$ to $1373 \mathrm{~K}\left(700{ }^{\circ} \mathrm{C}\right.$ to $\left.1100{ }^{\circ} \mathrm{C}\right)$ as a result of pyrolysis, while that of cokes increased slightly by heat treatment. Fracture toughness of IMDC was higher than RMDC. Macrostrength of carbonaceous materials was strongly affected by their porosity and microstrength. The effect of pore geometry on macrostrength was marginal. Decreasing the porosity was more effective compared with increasing the microstrength in improving the macrostrength of carbonaceous materials.
\end{abstract}

DOI: $10.1007 / \mathrm{s} 11663-013-9855-3$

(C) The Minerals, Metals \& Materials Society and ASM International 2013

\section{INTRODUCTION}

Carbonaceous materials are extensively used in ferrous metallurgy include metallurgical cokes, chars, and a variety of coals. Metallurgical cokes are a major type of material for blast furnace iron making, while chars and coals are used in direct iron smelting and ferroalloy-making processes. Replacing coke with coal and char would, however, lead to significant economic and environmental benefits. Carbonaceous materials with good mechanical strength are required to insure good permeability to liquid and gas phases flowing through the burden or coke bed in a ferroalloy furnace.

XING XING, Postdoctoral Fellow, and OLEG OSTROVSKI, Professor, are with the School of Materials Science and Engineering, University of New South Wales, Sydney, NSW 2052, Australia. Contact e-mail: x.xing@unsw.edu.au GUANGQING ZHANG, Lecturer, is with the School of Mechanical, Materials \& Mechatronic Engineering, University of Wollongong, Wollongong, NSW 2522. MARK DELL AMICO, Project Scientist, is with the CSIRO Energy Centre, 10 Murray Dwyer Circuit, Steel River Estate, Mayfield West, NSW 2304. GEORGE CIEZKI, Manager Production Planning \& Smelting Manganese, is with the Tasmanian Electro Metallurgical Company, PO Box 164, George Town, TAS 7253, Australia. QINGBO MENG, Vice-President, is with the Sinosteel Anshan Research Institute of Thermo-Energy Co., Ltd., Anshan, Liaoning, P.R. China. Manuscript submitted February 14, 2013.

Article published online April 30, 2013.
Heating of carbonaceous materials in the furnace strongly affects their mechanical properties. Upon heating, carbonaceous materials experience pyrolysis and change to their micro and macrostrengths. However, selection of carbonaceous materials to replace coke used in the production of ferroalloys is usually empirical, rather than based on examination of the variation in mechanical strength of the materials under a range of conditions in ferroalloy furnaces.

Macrostrength of carbonaceous materials has been intensively studied using different methods. ${ }^{[1-4]}$ Nakamura et al. ${ }^{[5]}$ suggested that coke strength was predominantly defined by the rank of parent coals; they found that cokes reached the maximum strength after reaction (CSR) when their parent coals had the mean reflectance ranging from 1.2 to 1.3 pet. Yip et al. ${ }^{[6]}$ observed that the compressive strength of char significantly increased with pyrolysis temperature $<1073 \mathrm{~K}\left(800^{\circ} \mathrm{C}\right)$. Decrease in the heating rate led to a significant degradation in the mechanical strength after reaction (as measured by CSR) ${ }^{[7]}$ Microstrength of carbonaceous materials has been investigated by ultramicro indentation, ${ }^{[8-11]}$ with a main focus on the hardness and Young's modulus. However, Andriopoulos et al. ${ }^{[10]}$ suggested that the macrostrength of carbonaceous materials was not directly related to the hardness or Young's modulus, but to the fracture toughness. Tomoki et al..$^{[9]}$ found that the Young's modulus of the matrix of metallurgical coke increased with rising pyrolysis temperature. Only a few reports are, however, found in the literature, which have 
studied the effect of annealing on the macrostrength and microstrength of carbonaceous materials, although these changes significantly affect the production efficiency of a submerged electric arc furnace.

Parameters determining the mechanical strength of carbonaceous materials have been intensively studied. ${ }^{[12-16]}$ Knibbs $^{[17]}$ established an empirical equation which correlates strength with grain size and porosity using an orientation correction for graphite:

$$
S=k d^{-0.5} \exp (-b P)
$$

where $S$ is the average bend strength, $k$ and $b$ are constants; $P$ is porosity, and $d$ is the maximum grain size identified by crack length.

Patrick et al. ${ }^{[18]}$ further developed Eq. [1] for cokes by replacing crack length with pore size measured by the maximum Feret diameter. They also found that the pore shape, represented by the Ferret ratio, is an important factor affecting the stress concentration.

$$
S=450\left(F_{\max }\right)^{-0.5} \exp \left(-2\left(\frac{F_{\max }}{F_{\min }}\right)^{0.5} P\right)
$$

where $F_{\max }$ and $F_{\min }$ are the maximum and the minimum Feret diameters, respectively.

Kim et al. ${ }^{[19]}$ simulated the effect of pore structure on coke strength using a 3D discrete element method, and established the following relationship between tensile strength and pore structure:

$$
\sigma_{\mathrm{c}}=450\left(1-P_{2 \mathrm{D}, \operatorname{Max}}\right) \exp (-7.3 P)
$$

where $\sigma_{\mathrm{c}}$ is critical tensile stress, and $P_{2 \mathrm{D}, \mathrm{Max}}$ is the maximum $2 \mathrm{D}$ porosity estimated by image analysis or CT scan.

Grant et al. ${ }^{[20]}$ derived an empirical equation to correlate cell wall size, pore size, and tensile strength:

$$
\sigma N=10^{5} \frac{W}{P^{2}}-K
$$

where $\sigma$ is tensile strength, $W$ is the thickness of cell wall, $N$ is the number of pores per field, $P$ is the pore size (mean chord length), and $K$ is a constant.

Previous studies mainly focus on the effect of pore structure on the mechanical strength of carbonaceous materials, and the effect of strength in the matrix of carbonaceous materials was not taken into consideration. Although it has been suggested that the mechanical strength of coke was affected by the pore structure and the fracture toughness of coke wall components, ${ }^{[10]}$ no study has reported a correlation between the mechanical strength of carbonaceous materials and their pore structure and matrix strength. The aim of this article is to study of the effect of heat treatment on macro and microstrengths of carbonaceous materials at temperatures ranging from $973 \mathrm{~K}$ to $1773 \mathrm{~K}\left(700{ }^{\circ} \mathrm{C}\right.$ to $1500{ }^{\circ} \mathrm{C}$ ), and develop a better understanding of the factors affecting mechanical strength of carbonaceous materials.

\section{EXPERIMENTAL}

\section{A. Materials}

Carbonaceous materials were supplied by Tasmanian Electro Metallurgical Company (Australia) and METALLOYS (South Africa); they included three coke samples, three char samples, and three coal samples. The proximate and petrographic analyses were reported previously. ${ }^{[21]}$

\section{B. Heat Treatment}

The coal samples were processed at the CSIRO Energy Centre in an 8-kg-retort furnace at $973 \mathrm{~K}$ $\left(700{ }^{\circ} \mathrm{C}\right)$ to remove volatile matter and obtain laboratory char samples (pyrolyzed coals). Approximately, $200 \mathrm{~g}$ of coke or char samples with particle sizes ranging from 19 to $21 \mathrm{~mm}$ was heat treated in a graphite furnace under argon atmosphere for 2 hours at temperatures of $973 \mathrm{~K}, 1173 \mathrm{~K}, 1373 \mathrm{~K}, 1573 \mathrm{~K}$, and $1773 \mathrm{~K}\left(700{ }^{\circ} \mathrm{C}\right.$, $900{ }^{\circ} \mathrm{C}, 1100{ }^{\circ} \mathrm{C}, 1300{ }^{\circ} \mathrm{C}$, and $1500^{\circ} \mathrm{C}$ ).

\section{Tensile Strength}

Cylindrical cores with 8-mm diameter were drilled from coke and char lumps, and then pellets with 7- to 8 -mm thickness range were cut from these cylindrical cores to make samples for tensile testing. The tensile strength was determined by testing 50 samples in the airdried condition on an Instron 1185 screw universal testing machine with $30 \mathrm{kN}$ load cell. The rate of load application was standardized at a machine cross-head speed of $0.5 \mathrm{~mm} / \mathrm{min}$. The tensile strength, $\sigma$, was calculated using equation below:

$$
\sigma=\frac{2 P}{\pi d l}
$$

where $P$ is load; and $d$ and $l$ are the diameter and the thickness of the cylindrical samples, respectively.

\section{Ultramicro Indentation}

Microstrength of carbonaceous materials was determined using a UMIS2000 ultramicro indentation system. Earlier indentation studies showed that while using a Berkovich indenter with a face angle of $65.27 \mathrm{deg}$, there was very little plastic deformation with no residual indenter impression after full load, or crack formation. ${ }^{[10]}$ Therefore, a sharper cube corner indenter, with a face angle of $35.26 \mathrm{deg}$, was used when a residual impression and measurable radial cracks were needed. Indentation was made on the resin-mounted, polished samples with an appropriate indenter. Measurements were carried out on both IMDC and RMDC.

\section{Hardness and Young's modulus}

A three-sided Berkovich indenter was applied to determine the hardness, $H$, and Young's modulus, $E$. A load of $100 \mathrm{mN}$ was applied, and at least 35 measurements for each type of microtexture of each carbonaceous material were carried out across several 
sample lumps. Hardness and Young's modulus were determined according to the loading-unloading curve generated by increasing the applied load and measuring the depth of penetration of a diamond indenter.

The hardness, $H$ and Young's modulus, $E$, were calculated according to the method developed by Oliver and Pharr $^{[22]}$ :

$$
h_{\mathrm{c}}=h_{\max }-0.72 \frac{P_{\max }}{d P / d h}
$$

where $P_{\max }$ is maximum applied load, $d P / d h$ is the slope of a tangent at initial unloading, $h_{\mathrm{c}}$ is the plastic penetration depth, and $h_{\max }$ is the maximum penetration. The contact area $A$ is calculated by Reference 23

$$
A=3 \sqrt{3} h_{c}^{2} \tan ^{2} \theta
$$

where $\theta$ is the face angle of applied indenter. The contact area for a Berkovich indenter with $\theta=65.27 \mathrm{deg}$ is calculated as

$$
A=24.5 h_{\mathrm{c}}^{2}
$$

The hardness, $H$ and Young's modulus, $E$, are given by Reference 22 :

$$
\begin{gathered}
H=\frac{P_{\max }}{A} \\
E=\frac{1}{2} \frac{d P}{d h} \frac{\sqrt{\pi}}{\sqrt{A}}
\end{gathered}
$$

\section{Fracture toughness}

The measurement of fracture toughness relies upon the optical measurement of the crack length of residual impression formed after indentation. The fracture toughness $K_{1 c}$ was calculated as ${ }^{[23]}$

$$
K_{1 c}=k\left(\frac{E}{H}\right)^{n} \frac{P_{\max }}{c^{3 / 2}}
$$

where $c$ is crack length; constant $k$ and exponent $n$ depend on the geometry of applied indenter. For the cube corner indenter, $k=0.036$ and $n=1 / 2$.

Fracture toughness of carbonaceous materials was determined using 50 and $100 \mathrm{mN}$ loads with cube corner indenter. Both IMDC and RMDC were indented, each at 15 different locations, and crack lengths of residual impression after full unload were measured from the images obtained by the digital camera linked to the microscope of the UMIS.

\section{RESULTS}

\section{A. Effect of Heat Treatment on Tensile Strength of Carbonaceous Materials}

Tensile strengths of original carbonaceous materials, before and after annealing at different temperatures, are presented in Table I. These varied widely in the range from 2.0 to $8.5 \mathrm{MPa}$, depending on the type of material. Cokes had the highest tensile strength among the three types of carbonaceous materials.

Annealing at temperatures $\leq 1573 \mathrm{~K}\left(1300^{\circ} \mathrm{C}\right)$ caused marginal decrease in tensile strength, while the effect was more significant after annealing at $1773 \mathrm{~K}\left(1500{ }^{\circ} \mathrm{C}\right)$. Over 14 pct decrease in tensile strength was observed for Coke 1 after heat treatment at $1773 \mathrm{~K}\left(1500{ }^{\circ} \mathrm{C}\right)$. This coke had the highest tensile strength before and after annealing.

Tensile strength of original chars varied from 2.54 to 6.17 $\mathrm{MPa}$ depending on the type of the char. After annealing at $1773 \mathrm{~K}\left(1500{ }^{\circ} \mathrm{C}\right)$, tensile strength of Char 1 and Char 2 increased by 32 and 14 pet to 5.3 and $2.9 \mathrm{MPa}$, respectively. In contrast, heat treatment slightly decreased the tensile strength of Char 3 from 6.2 to $5.9 \mathrm{MPa}$.

Tensile strength of original coals was approximately $3 \mathrm{MPa}$. In the process of heating, coals softened progressively, and reached maximum fluidity between $623 \mathrm{~K}$ and $723 \mathrm{~K}\left(350{ }^{\circ} \mathrm{C}\right.$ and $\left.450{ }^{\circ} \mathrm{C}\right)$. With further increase of temperature from $723 \mathrm{~K}$ to $823 \mathrm{~K}\left(450{ }^{\circ} \mathrm{C}\right.$ to $550{ }^{\circ} \mathrm{C}$ ), coals started losing its fluidity and hardening to transform into char. Microstrength and pore structure of coals changed dramatically during this process, thereby influencing the macrostrength of the char derived from coal (pyrolyzed coal). Tensile strength of pyrolyzed coals produced at $973 \mathrm{~K}\left(700{ }^{\circ} \mathrm{C}\right)$ had the tensile strength in the range from 2.0 to $3.4 \mathrm{MPa}$. Further annealing from $973 \mathrm{~K}$ to $1773 \mathrm{~K}\left(700{ }^{\circ} \mathrm{C}\right.$ to $1500{ }^{\circ} \mathrm{C}$ ) increased the tensile strength of all pyrolyzed coals to approximately $4 \mathrm{MPa}$, and the rate of this

Table I. Tensile Strength of Original Carbonaceous Materials and After Annealing at Different Temperatures (MPa)

\begin{tabular}{lccccc}
\hline & Original & $973 \mathrm{~K}\left(700{ }^{\circ} \mathrm{C}\right)$ & $1373 \mathrm{~K}\left(1100{ }^{\circ} \mathrm{C}\right)$ & $1573 \mathrm{~K}\left(1300{ }^{\circ} \mathrm{C}\right)$ & $1773 \mathrm{~K}\left(1500{ }^{\circ} \mathrm{C}\right)$ \\
\hline Coke 1 & 8.47 & - & - & 8.26 & 6.85 \\
Coke 2 & 6.94 & - & - & 7.09 & 7.25 \\
Coke 3 & 7.14 & - & 5.16 & - & 6.43 \\
Char 1 & 4.02 & - & 2.88 & - & 5.29 \\
Char 2 & 2.54 & - & 5.80 & - & 5.94 \\
Char 3 & 6.17 & 2.00 & 3.85 & - & 4.12 \\
Coal 1 & 3.28 & 3.44 & 3.92 & - & 4.08 \\
Coal 2 & 2.91 & 2.36 & 3.67 & \\
Coal 3 & 3.20 & & &
\end{tabular}


increase was higher in the temperature range from $973 \mathrm{~K}$ to $1373 \mathrm{~K}\left(700{ }^{\circ} \mathrm{C}\right.$ to $\left.1100{ }^{\circ} \mathrm{C}\right)$.

\section{B. Inherent Strength of Carbonaceous Materials}

Results of tensile testing of carbonaceous materials, where breakage occurs by brittle fracture, have a significant scattering which is common to many other brittle materials. In the conventional normal distribution, the mean value of experimental data is considered as the true value, and the standard deviation characterizes the experimental uncertainty of the test. However, for tensile strength of carbonaceous materials, the variations of data are caused by the heterogeneous nature of the materials in porosity, microstrength, and surface and/or internal defects. Therefore, under the same testing conditions, fracture can occur at very different pressures. Experimental data obtained during tensile testing of carbonaceous materials are appropriately processed using Weibull statistical theory ${ }^{[24]}$ which is based on the analysis of probability of failure. Following the Weibull statistical theory, the probability of fracture $P$ under pressure $\tau$ can be described by References 24, 25:

$$
1-P=\exp \left[-\left(\frac{\tau}{\tau_{0}}\right)^{m}\right]
$$

where $\tau_{0}$ and $m$ are constants. $\tau_{0}$ is a material constant referred to as inherent strength, and $m$ is Weibull modulus related to homogeneity of material. In the above equation, $(1-P)$ represents the probability of material's survival. Eq. [12] can be transformed to Eq. [13]:

$$
\ln \left(\ln \frac{1}{1-P}\right)=m \ln (\tau)-m \ln \left(\tau_{0}\right)
$$

Therefore, if Weibull theory holds for the materials, then a plot of $\ln (\ln 1 /(1-P))$ against $\ln (\tau)$ would give straight line.

The probability of fracture, $P$, can be calculated as a fraction of samples fractured at a particular level of pressure. $^{[26]}$ Probability of fracture of carbonaceous materials under different pressures is plotted in Figure 1 for original Coke 2 and pyrolyzed Coal 1 annealed at $973 \mathrm{~K}\left(700{ }^{\circ} \mathrm{C}\right)$. These data are used for analysis of material strength by the application of Weibull statistical theory.

The inherent strength $\tau_{0}$ of different carbonaceous materials was obtained from the plots of $\ln (\ln 1 /(1-P))$ against $\ln (\tau)$ and are listed in Table II.

Calculated inherent strength was slightly higher than mean tensile strength; however, the two parameters have a good linear correlation as shown in Figure 2.

\section{Effect of Heat Treatment on Fracture Toughness of Carbonaceous Materials}

Fracture of carbonaceous materials was calculated using experimental data on hardness, Young's modulus, and crack length of residual impression after indentation. Table III lists the fracture toughness of original carbonaceous materials and the same materials annealed at different temperatures. The overall microstrength of cokes was calculated from the volume fractions of IMDC and RMDC in each coke, and their fracture toughness values. It represents the weight-averaged microstrength of a carbonaceous material and was used to correlate with macrostrengths of the carbonaceous material (Section IV-B).

Fracture toughness values of IMDC of original cokes ranged from 1.4 to $1.5 \mathrm{MPa} \mathrm{m}^{1 / 2}$, slightly higher than $\mathrm{RMDC}$ which ranged from 1.0 to $1.2 \mathrm{MPa} \mathrm{m}^{1 / 2}$. Heat treatment had no effect on the fracture toughness of IMDC but slightly increased that of RMDC. RMDC of cokes was derived from reactive macerals in the parent coals; condensation reactions continued during heat treatment and, as a result, the microstrength of RMDC slightly increased after heat treatment at $1773 \mathrm{~K}$ $\left(1500{ }^{\circ} \mathrm{C}\right)$. Inert components have more condensed aromatic rings than reactive components; condensation reaction of IMDC was completed during coke-making process at approximately $1273 \mathrm{~K}\left(1000{ }^{\circ} \mathrm{C}\right)$ for 16 through 18 hours. Thus, change in fracture toughness of IMDC was not expected. Overall fracture toughness values of original Coke 1 and Coke 3 were approxi-
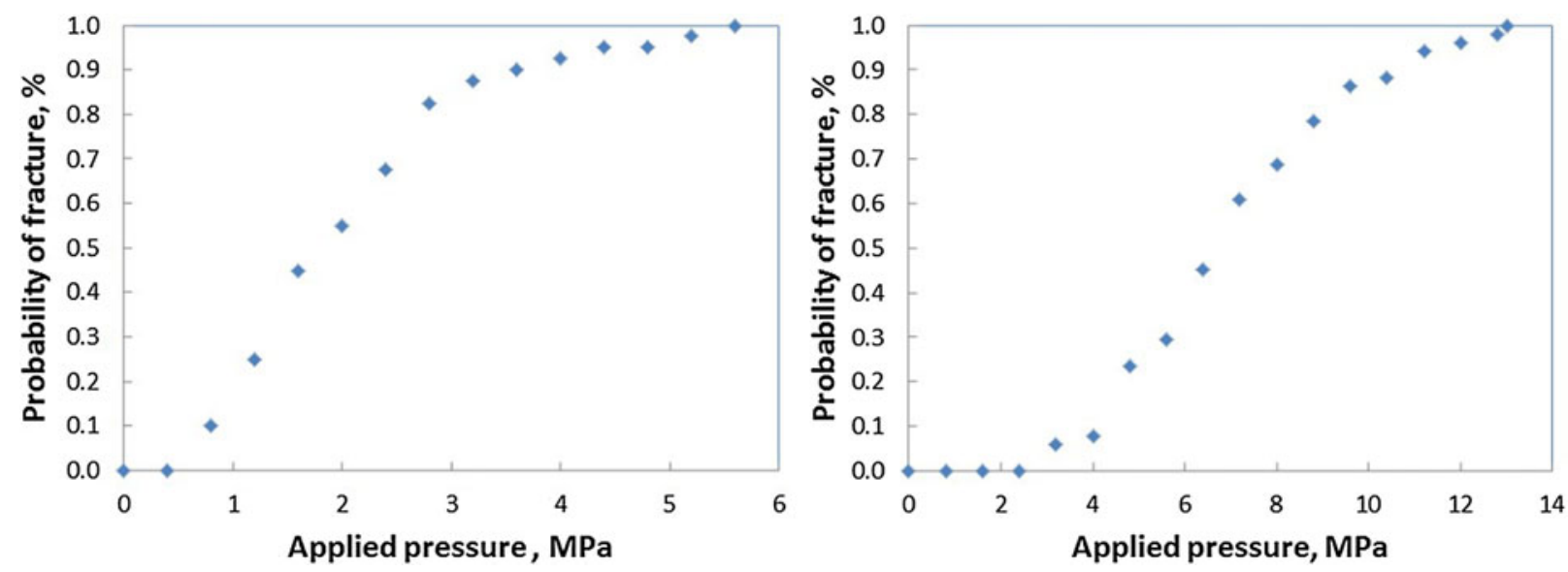

Fig. 1-Probability of fracture of Coal 1 annealed at $973 \mathrm{~K}\left(700^{\circ} \mathrm{C}\right)$ and original Coke 2. 
Table II. Inherent Strength $\tau_{0}$ of Carbonaceous Materials Before and After Annealing at Different Temperatures (MPa)

\begin{tabular}{|c|c|c|c|c|c|}
\hline & Original & $973 \mathrm{~K}\left(700^{\circ} \mathrm{C}\right)$ & $1373 \mathrm{~K}\left(1100^{\circ} \mathrm{C}\right)$ & $1573 \mathrm{~K}\left(1300^{\circ} \mathrm{C}\right)$ & $1773 \mathrm{~K}\left(1500{ }^{\circ} \mathrm{C}\right)$ \\
\hline Coke 1 & 9.37 & - & - & 9.04 & 7.99 \\
\hline Coke 2 & 7.86 & - & - & 7.67 & 7.08 \\
\hline Coke 3 & 8.24 & - & - & 8.02 & 7.62 \\
\hline Char 1 & 4.49 & - & 5.81 & - & 6.05 \\
\hline Char 2 & 2.86 & - & 3.25 & - & 3.49 \\
\hline Char 3 & 6.92 & - & 6.51 & - & 6.64 \\
\hline Coal 1 & 3.48 & 2.38 & 4.35 & - & 4.69 \\
\hline Coal 2 & 3.33 & 3.83 & 4.37 & - & 4.58 \\
\hline Coal 3 & 3.61 & 2.60 & 4.21 & - & 4.40 \\
\hline
\end{tabular}

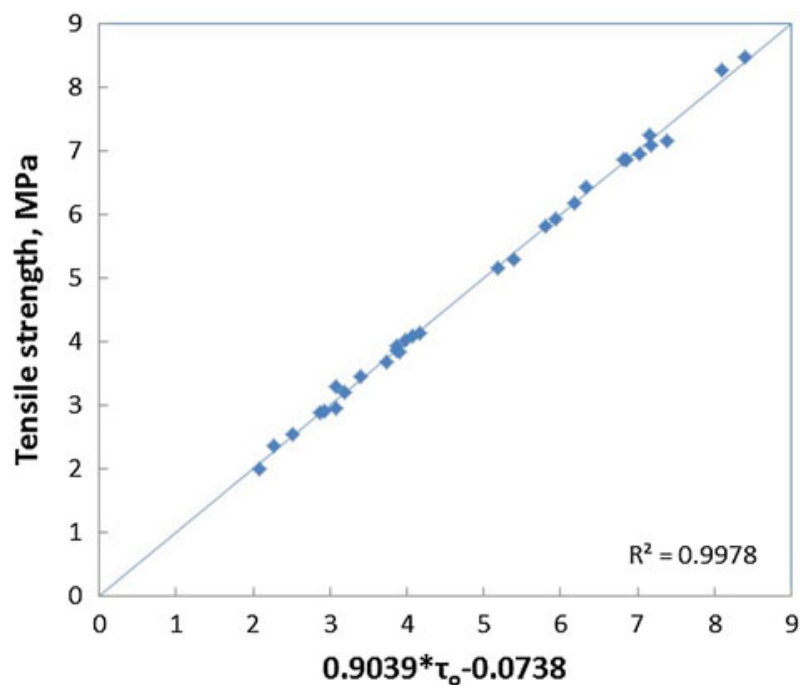

Fig. 2 - Correlation between tensile strength and inherent strength.

mately $1.3 \mathrm{MPa} \mathrm{m}^{1 / 2}$, which was higher than that of Coke $2\left(1.1 \mathrm{MPa} \mathrm{m}^{1 / 2}\right)$. Fracture toughness of all cokes was slightly enhanced by heat treatment at $1773 \mathrm{~K}$ $\left(1500^{\circ} \mathrm{C}\right)$ for 2 hours as a result of an increase in the fracture toughness in RMDC.

Fracture toughness of chars and pyrolyzed coals was represented by that of IMDC. Fracture toughness of original chars was approximately $0.49 \mathrm{MPa} \mathrm{m}{ }^{1 / 2}$. Heat treatment resulted in a significant enhancement of the microstrength of all chars. After annealing at $1773 \mathrm{~K}$ $\left(1500{ }^{\circ} \mathrm{C}\right)$ for 2 hours, over 80 pct increase of fracture toughness was observed for Char 1, which was the largest enhancement among three chars. Increase in the fracture toughness values were 48 pct for Char 2 and 30 pct for Char 3. The major enhancement took place in annealing at temperatures $<1373 \mathrm{~K}\left(1100{ }^{\circ} \mathrm{C}\right)$; further increase in heat treatment temperature only caused a marginal increase.

The fracture toughness of original coals was low, approximately $0.20 \mathrm{MPa} \mathrm{m}^{1 / 2}$. Pyrolysis of coals enhanced their microstrength. Fracture toughness values of Coals 2 and 3 pyrolyzed at $973 \mathrm{~K}\left(700^{\circ} \mathrm{C}\right)$ were about $0.40 \mathrm{MPa} \mathrm{m}{ }^{1 / 2}$, and pyrolyzed Coal 1 had lower fracture toughness of, $0.34 \mathrm{MPa} \mathrm{m}{ }^{1 / 2}$. Heat treatment increased the microstrength of all pyrolyzed coals in the same manner as the supplied chars. Most significant increase in microstrength of pyrolyzed coals took place in the temperature range from $973 \mathrm{~K}$ to $1373 \mathrm{~K}\left(700{ }^{\circ} \mathrm{C}\right.$ to $1100{ }^{\circ} \mathrm{C}$ ), in which the fracture toughness was doubled. Further increase of annealing temperature from $1373 \mathrm{~K}$ to $1773 \mathrm{~K}\left(1100{ }^{\circ} \mathrm{C}\right.$ to $\left.1500{ }^{\circ} \mathrm{C}\right)$ caused $<10$ pct increase in microstrength. After heat treatment at $1773 \mathrm{~K}\left(1500{ }^{\circ} \mathrm{C}\right)$ for 2 hours, pyrolyzed coals were four times as strong as the original coals.

\section{DISCUSSION}

\section{A. Factors Affecting Microstrength of Carbonaceous Materials from Heat Treatment}

Changes in fracture toughness during annealing can be attributed to pyrolysis of carbonaceous materials. Pyrolysis of cokes was almost completed during the coke making. Volatile release of cokes during heat treatment was approximately $0.5 \mathrm{wt}$ pct. ${ }^{[1]}$ As a result, microstrength of cokes was slightly affected by annealing with only approximately 5 pct increase in the fracture toughness observed after annealing at $1773 \mathrm{~K}\left(1500{ }^{\circ} \mathrm{C}\right)$ (Table III).

Greater enhancement of microstrength by annealing was observed for chars and pyrolyzed coals as the result of their further pyrolysis. Major pyrolysis of chars and coals and increase in their strength took place in the annealing at temperatures $<1373 \mathrm{~K}\left(1100{ }^{\circ} \mathrm{C}\right)$. Further increase of heat-treatment temperature ranging from $1373 \mathrm{~K}$ to $1773 \mathrm{~K}\left(1100{ }^{\circ} \mathrm{C}\right.$ and $\left.1500{ }^{\circ} \mathrm{C}\right)$ caused a marginal pyrolysis and, as a result, a slight increase of microstrength.

Relationships between fracture toughness and volatile matter ${ }^{[21]}$ in original chars and coals, and chars and pyrolyzed coals annealed at $973 \mathrm{~K}\left(700^{\circ} \mathrm{C}\right)$ and $1373 \mathrm{~K}$ $\left(1100^{\circ} \mathrm{C}\right)$ are shown in Figure 3.

Devolatilization of over 80 pct during pyrolysis of coals at $973 \mathrm{~K}\left(700{ }^{\circ} \mathrm{C}\right)$ significantly increased their microstrength from 0.2 to $0.4 \mathrm{MPa} \mathrm{m}^{1 / 2}$. Annealing at $1373 \mathrm{~K}\left(1100{ }^{\circ} \mathrm{C}\right)$ caused a sharp increase in fracture toughness without significant amount of volatile matter release.

A relationship between devolatilization of carbonaceous materials and toughness strength can be interpreted as follows. In the earlier stage of pyrolysis of coals, the aliphatic structure of coals with weaker bonds were decomposed from the aromatic structure and released in the form of volatile matter, causing a sharp decrease in $\mathrm{H} / \mathrm{C}$ ratio in the materials. Removal of the 
Table III. Fracture Toughness of Original Carbonaceous Materials and After Annealing at Different Temperatures

\begin{tabular}{|c|c|c|c|}
\hline & IMDC $\left(\mathrm{MPa} \mathrm{m}^{1 / 2}\right)$ & $\operatorname{RMDC}\left(\mathrm{MPa} \mathrm{m}^{1 / 2}\right)$ & Overall $\left(\mathrm{MPa} \mathrm{m}^{1 / 2}\right)$ \\
\hline Coke 1 Original & 1.39 & 1.18 & 1.26 \\
\hline Coke $11773 \mathrm{~K}\left(1500^{\circ} \mathrm{C}\right)$ & 1.40 & 1.22 & 1.30 \\
\hline Coke 2 Original & 1.35 & 0.97 & 1.11 \\
\hline Coke $21773 \mathrm{~K}\left(1500^{\circ} \mathrm{C}\right)$ & 1.34 & 1.06 & 1.15 \\
\hline Coke 3 Original & 1.51 & 1.16 & 1.25 \\
\hline Coke $31773 \mathrm{~K}\left(1500^{\circ} \mathrm{C}\right)$ & 1.51 & 1.21 & 1.31 \\
\hline Char 1 Original & 0.51 & - & 0.51 \\
\hline Char $11373 \mathrm{~K}\left(1100^{\circ} \mathrm{C}\right)$ & 0.88 & - & 0.88 \\
\hline Char $11773 \mathrm{~K}\left(1500^{\circ} \mathrm{C}\right)$ & 0.95 & - & 0.95 \\
\hline Char 2 Original & 0.50 & - & 0.50 \\
\hline Char $21373 \mathrm{~K}\left(1100^{\circ} \mathrm{C}\right)$ & 0.68 & - & 0.68 \\
\hline Char $21773 \mathrm{~K}\left(1500^{\circ} \mathrm{C}\right)$ & 0.72 & - & 0.72 \\
\hline Char 3 Original & 0.42 & - & 0.42 \\
\hline Char $31773 \mathrm{~K}\left(1500^{\circ} \mathrm{C}\right)$ & 0.55 & - & 0.55 \\
\hline Coal 1 Original & 0.22 & - & 0.22 \\
\hline Coal $1973 \mathrm{~K}\left(700^{\circ} \mathrm{C}\right)$ & 0.34 & - & 0.34 \\
\hline Coal $11373 \mathrm{~K}\left(1100^{\circ} \mathrm{C}\right)$ & 0.77 & - & 0.77 \\
\hline Coal $11773 \mathrm{~K}\left(1500^{\circ} \mathrm{C}\right)$ & 0.84 & - & 0.84 \\
\hline Coal 2 Original & 0.18 & - & 0.18 \\
\hline Coal $2973 \mathrm{~K}\left(700^{\circ} \mathrm{C}\right)$ & 0.40 & - & 0.40 \\
\hline Coal $21373 \mathrm{~K}\left(1100^{\circ} \mathrm{C}\right)$ & 0.81 & - & 0.81 \\
\hline Coal $21773 \mathrm{~K}\left(1500^{\circ} \mathrm{C}\right)$ & 0.85 & - & 0.85 \\
\hline Coal 3 Original & 0.22 & - & 0.22 \\
\hline Coal $3973 \mathrm{~K}\left(700^{\circ} \mathrm{C}\right)$ & 0.39 & - & 0.39 \\
\hline Coal $31373 \mathrm{~K}\left(1100^{\circ} \mathrm{C}\right)$ & 0.85 & - & 0.85 \\
\hline Coal $31773 \mathrm{~K}\left(1500^{\circ} \mathrm{C}\right)$ & 0.95 & - & 0.95 \\
\hline
\end{tabular}

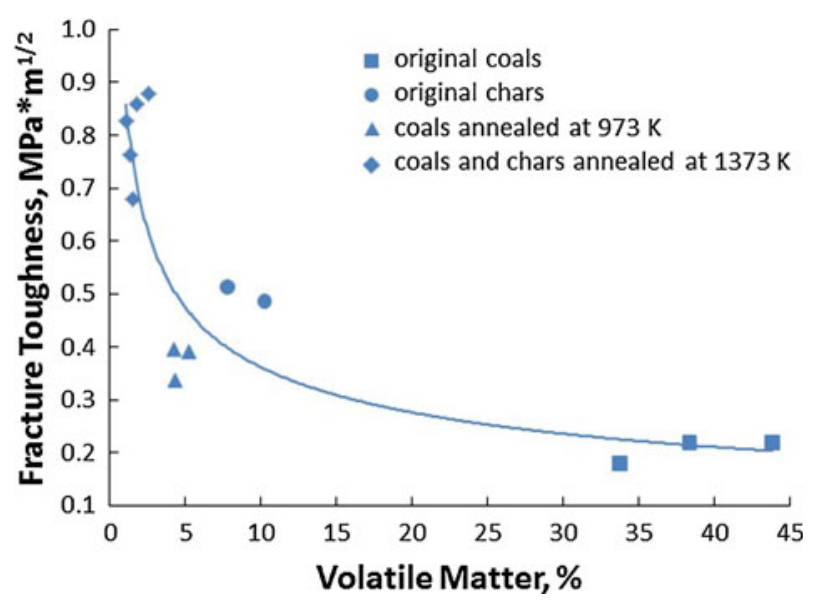

Fig. 3-Relationship between fracture toughness and volatile matter in original chars and coals, pyrolyzed coals annealed at $973 \mathrm{~K}$ $\left(700{ }^{\circ} \mathrm{C}\right)$, and chars and pyrolyzed coals annealed at $1373 \mathrm{~K}$ $\left(1100^{\circ} \mathrm{C}\right)$.

volatile matter was accompanied by condensation reaction of aromatic rings which strengthened the material, which was manifested in the form of the increase of fracture toughness. With a further increase of heattreatment temperature ranging from $973 \mathrm{~K}$ to $1373 \mathrm{~K}$ $\left(700{ }^{\circ} \mathrm{C}\right.$ to $\left.1100{ }^{\circ} \mathrm{C}\right)$, devolatilization was close to completion, and the main reaction in carbonaceous material was that of condensation. Aromatic structures condensed together by dehydrogenation to form large and condensed aromatic structures with strong bonds and enhanced resistance to fracture. At this stage, the fracture toughness increased with a small amount of release of volatile matter, which was probably predominantly of hydrogen.

An increase in the fracture toughness of chars and pyrolyzed coals in the temperatures ranging from $1373 \mathrm{~K}$ to $1773 \mathrm{~K}\left(1100{ }^{\circ} \mathrm{C}\right.$ to $\left.1500{ }^{\circ} \mathrm{C}\right)$ can also be explained by the subsequent condensation of carbonaceous materials, in which devolatilization was only 0.8 wt pet.

\section{B. Correlation Between Macro and Microstrengths}

The macrostrength of carbonaceous materials would be expected to be related to their microstrength. Attempts have been made to correlate the tensile strength of carbonaceous materials with their overall fracture toughness measured using ultramicro indentation. Figure 4 shows the relationship between inherent strength and fracture toughness, the former being linearly correlated with tensile strength as shown in Section III-B. The inherent strength of carbonaceous materials generally increased with increasing fracture toughness; however, the small correlation coefficient $\left(R^{2}=0.593\right)$ indicates that microstrength was not the single parameter affecting the macrostrength of carbonaceous materials.

The macrostrength of carbonaceous materials can also be affected by porosity and pore geometry. The porosity and pore geometry parameters were determined by image analysis and reported in part 2 of this series of articles. $^{[27]}$ A correlation between pore structure, microstrength, and inherent strength was presented by empirical Eq. [14]: 


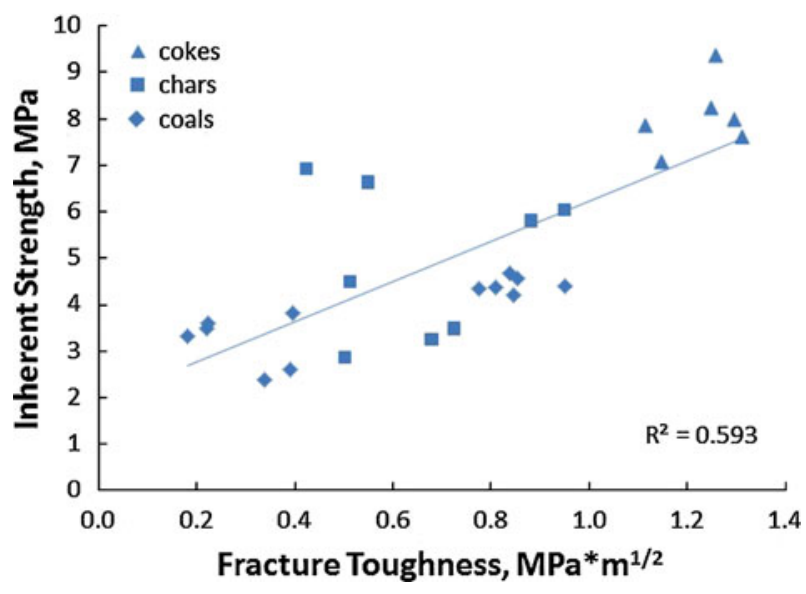

Fig. 4 - Correlation between inherent strength and fracture toughness.

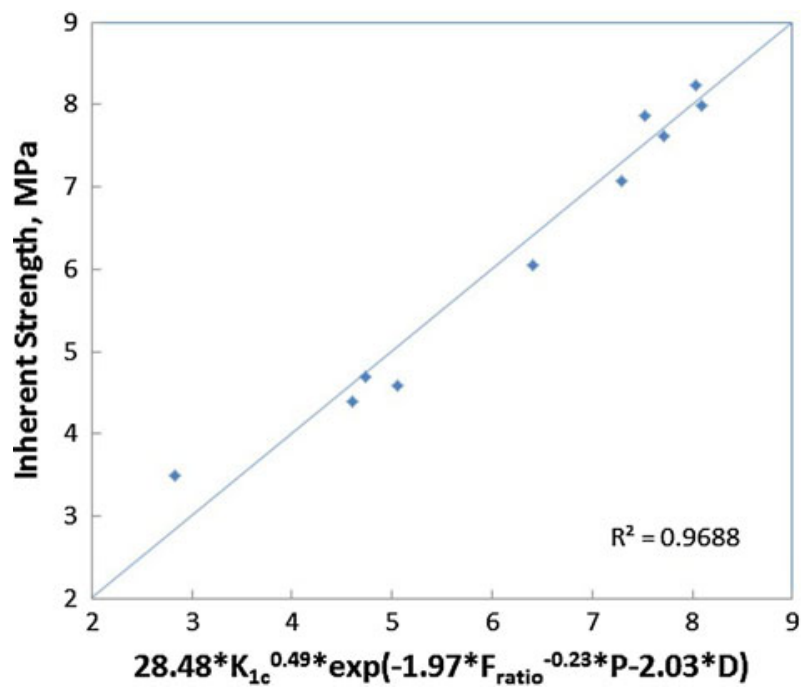

Fig. 5-Correlation of inherent strength with pore geometry, porosity, and fracture toughness.

$$
\tau_{o}=28.48 K_{1 c}^{0.49} \exp \left(-1.97 F_{\text {ratio }}^{-0.23} p-2.03 D\right)
$$

where $D$ and $F_{\text {ratio }}$ represent equivalent circle diameter of pores and Feret ratio, and $p$ is porosity. Figure 5 shows that inherent strength has a good correlation with pore geometry, porosity, and fracture toughness ( $R^{2}=0.9688$ ) following Eq. [14]. It is seen from the equation that inherent strength increases with fracture toughness and Feret ratio, but is inversely affected by porosity and equivalent circle diameter of pores.

Ignoring the effect of pore geometry, correlation of inherent strength with porosity and microstrength is described by Eq. [15]:

$$
\tau_{o}=18.19 K_{1 c}^{0.80} \exp (-1.91 p)
$$

Figure 6 shows that inherent strength is well correlated with porosity and fracture toughness following Eq. [15]. It can be concluded that the pore geometry only has a marginal effect on the inherent strength of the

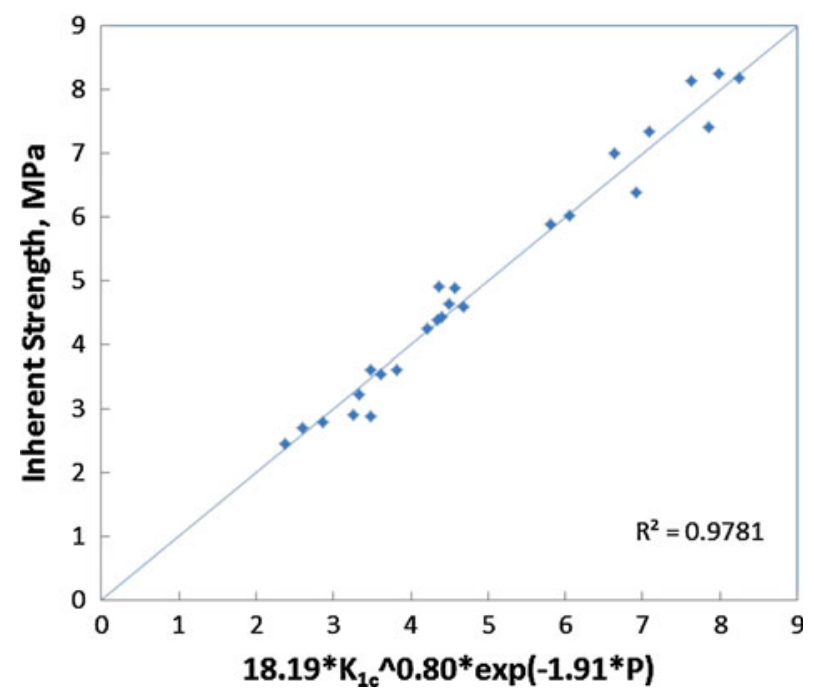

Fig. 6-Correlation of inherent strength with porosity and fracture toughness.

carbonaceous materials. Note that the correlation coefficient in Figure 6 is slightly larger than that in Figure 5 because more data are included in Figure 6. It does not mean that Eq. [15] has a better correlation than Eq. [14].

This result indicates that macrostrength of carbonaceous materials can be improved by reducing porosity and/or increasing microstrength. The comparative effect of these parameters on the macrostrength can be illustrated as follows.

If one parameter is fixed, and the other parameter is varied by a fraction " $x$ " (increase for fracture toughness; decrease for porosity), then the change of inherent strength $\Delta \tau$ can be calculated using Eqs. [15] and [16].

$$
\Delta \tau=\frac{\tau_{o}^{\prime}-\tau_{o}}{\tau_{o}}
$$

The change of inherent strength caused by increasing fracture toughness by " $x$ " $I_{K_{1 c}}$, will be

$$
I_{K_{1 c}}=(1+x)^{0.80}-1
$$

The change of inherent strength caused by porosity reduction by $x, I_{\mathrm{p}}$ will be

$$
I_{\mathrm{p}}=\exp (1.91 \times p)-1
$$

where $\mathrm{p}$ is the original porosity of materials before porosity reduction. According to Eqs. [17] and [18], when the original porosity of a material is larger than 42 pct, the improvement of inherent strength caused by porosity reduction, $I_{\mathrm{p}}$, is greater than that caused by the increase of fracture toughness, $I_{k 1 c}$. In this case, porosity has more significant effect than microstrength on the macrostrength of carbonaceous materials.

Only two coke/char samples employed in the current study had the porosity lower than $42 \mathrm{pct}$; therefore, decreasing the porosity is more effective than increasing microstrength for improving the macrostrength of carbonaceous materials. 


\section{CONCLUSIONS}

Macro and microstrengths of carbonaceous materials were studied by tensile test and ultramicro indentation. Macrostrength of carbonaceous materials was correlated with their pore structure and microstrength. The major findings are summarized as follows:

1. Cokes had the highest macro and microstrengths than the other two types of carbonaceous materials.

2. Tensile strength of chars and pyrolyzed coals was strongly enhanced by heat treatment (except Char 3 which tensile strength was slightly decreased by heat treatment).Tensile strength of cokes slightly degraded by heat treatment. Major enhancement of tensile strength of chars and pyrolyzed coals took place during annealing at temperatures ranging from $973 \mathrm{~K}$ to $1373 \mathrm{~K}\left(700{ }^{\circ} \mathrm{C}\right.$ to $\left.1100{ }^{\circ} \mathrm{C}\right)$; further increasing the temperature to $1773 \mathrm{~K}\left(1500{ }^{\circ} \mathrm{C}\right)$ had only a minor effect. Annealing of cokes at temperatures $\leq 1573 \mathrm{~K}\left(1300{ }^{\circ} \mathrm{C}\right)$ caused marginal decrease in tensile strength of cokes; decrease in the coke strength after annealing at $1773 \mathrm{~K}\left(1500{ }^{\circ} \mathrm{C}\right)$ was more evident.

3. Fracture toughness of chars and pyrolyzed coals was strongly enhanced by heat treatment, particularly attempertures ranging from $973 \mathrm{~K}$ to $1373 \mathrm{~K}\left(700{ }^{\circ} \mathrm{C}\right.$ to $1100{ }^{\circ} \mathrm{C}$ ), while those of cokes were slightly increased by heat treatment. Fracture toughness of IMDC was higher than of RMDC. Heat treatment had no effect on the fracture toughness of IMDC but slightly increased that of RMDC. Enhancement of microstrength of carbonaceous materials was mainly caused by the pyrolysis during heat treatment.

4. The macrostrength of carbonaceous materials was strongly affected by the porosity and microstrength. The effect of pore geometry on macrostrength was marginal. Decreasing porosity was a more effective compared with increasing the microstrength in improving the macrostrength of carbonaceous materials.

\section{ACKNOWLEDGMENT}

This project was financially supported by Tasmanian Electrometallurgical Company and Australian Research
Council (ARC Linkage Project LP 098493). Pyrolyzed coal samples were prepared at CSIRO Energy Centre, Newcastle, Australia.

\section{REFERENCES}

1. K. Leibrock and H. Petak: Fuel Process Technol., 1983, vol. 7 (2), pp. 91-107.

2. M. Košina and P. Heppner: Fuel, 1985, vol. 64, pp. 53-58.

3. K. Amamoto: Fuel, 1997, vol. 76 (1), pp. 17-21.

4. R. Álvarez, M.A. Díez, C. Barriocanal, E. Díaz-Faes, and J.L.G. Cimadevilla: Fuel, 2007, vol. 86 (14), pp. 2159-66.

5. N. Nakamura, Y. Togino, and T. Tateoka: Ironmak. Steelmak., 1978, vol. 5, pp. 1-17.

6. K.V. Yip, H. Wu, D.K Zhang, and J. Coleman: Report No. 72, Curtin University of Technology, Griffin Coal Mining, Australia, May 2007.

7. D. Vogt and M. Depoux: Fuel Process. Technol., 1990, vol. 24, pp. 99-105.

8. D.T. Marx and L. Riester: Carbon, 1999, vol. 37 (11), pp. 1679-84.

9. O. Tomoki, U. Kenta, M. Yoshio, A. Hideyuki, M. Takatoshi, U. Takatoshi, and F. Koichi: Tetsu to Hagane, 2006, vol. 92 (3), pp. 171-76.

10. N. Andriopoulos, C.E. Loo, R. Dukino, and S.J. McGuire: ISIJ Int., 2003, vol. 43 (10), pp. 1528-37.

11. J.S. Fielda and M.V. Swain: Carbon, 1996, vol. 34 (11), pp. $1357-$ 66.

12. H. Sato, J.W. Patrick, and A. Walker: Fuel, 1998, vol. 77 (11), pp. $1203-08$

13. J.W. Patrick and A.E. Stacey: Fuel, 1978, vol. 57 (5), pp. 258-64.

14. J.W. Patrick and A.E. Stacey: Fuel, 1975, vol. 54 (4), pp. 256-64.

15. Y. Kubota, S. Nomura, T. Arima, and K. Kato: Tetsu-to-Hagane, 2010, vol. 96 (5), p. 328.

16. J.W. Patrick and A. Walker: Fuel, 1985, vol. 64 (1), pp. 136-38.

17. R.H. Knibbs: J. Nucl. Mater., 1967, vol. 24 (2), pp. 174-87.

18. J.W. Patrick and A. Walker: Carbon, 1989, vol. 27 (1), pp. 117-23.

19. S.Y. Kim and Y. Sasaki: ISIJ Int., 2010, vol. 50 (6), pp. 813-21.

20. M.G.K. Grant, A.C.D. Chaklader, and J.T. Price: Fuel, 1991, vol. 70 (2), pp. 181-88.

21. X. Xing: Ph.D. Thesis, School of Material Science and Engineering, University of New South Wales, 2012, pp. 71-86.

22. W.C. Oliver and G.M. Pharr: J. Mater. Res., 1992, vol. 7 (6), pp. $1564-83$.

23. A.C. Fischer-Cripps: The IBIS Handbook of Nanoindentation, 1st ed., Forestville, Fischer-Cripps Laboratories, 2009, p. 44.

24. W. Weibull: J. Appl. Mech., 1951, vol. 18, p. 293.

25. J.F. McCabe and T.E. Carrick: Dent. Mater., 1986, vol. 2 (4), pp. 139-42.

26. J.W. Patrick, A.E. Stacey, and H.C. Wilkinson: Fuel, 1972, vol. 51 (3), pp. 174-79.

27. X. Xing, G. Zhang, M. Dell'Amico, G. Ciezki, Q. Meng, and O. Ostrovski: Metall. Mater. Trans. B, in press. 